\title{
INTEGRATED USE OF ORGANIC AND INORGANIC FERTILIZERS ON MAIZE (Zea mays $L$.) YIELD AND SOIL FERTILITY IN ANDISOLS SOIL OF SIDAMA, ETHIOPIA
}

\author{
Melkamu Hordofa Sigaye ${ }^{1}$, Ribka Mekuria ${ }^{1}$, Kidist Kebede ${ }^{1}$, Ashenafi Nigussei ${ }^{1}$ and Belstie lulie ${ }^{2}$ \\ ${ }^{1}$ Ethiopian Institute of Agricultural Research Institute, Wondo Genet Agri. Research Center \\ Shashemane Ethiopia. \\ ${ }^{2}$ Ethiopian Institute of Agricultural Research Institute, Debre Markos Agri. Research Center Debre \\ Markos Ethiopia. \\ Corresponding Author: Melkamu Hordofa Sigaye: Email: hordofa.mel@gmail.com or \\ melkamu.hordofa@eiar.gov.et
}

\begin{abstract}
The study was carried out to determine the influence of organic and inorganic fertilizers on maize yield and soil fertility; to determine economically optimum organic and inorganic fertilizer combinations for maize production. The study was performed in a randomized complete block design consisting of 10 treatments and 3 replications. The treatments were: Control, 100\% of R-NP (138 N and $92 \mathrm{P}), 100 \%$ of vermicompost, $100 \%$ of conventional compost, $25 \% R-N P+75 \%$ of vermicompost, $50 \%$ of $R-N P+50 \%$ of vermicompost, $75 \%$ of $R-N P+25 \%$ of from vermicompost, $25 \%$ of $R-N P+75 \%$ of conventional compost, $50 \%$ of $R-N P+50 \%$ of conventional-compost, $75 \%$ of $R-N P+25 \%$ of conventional-compost. All rates of vermicompost and conventional compost were applied based on $N$ equivalence. Results indicate that applications of inorganic fertilizers with a combination of organic source fertilizers were increases maize yield and yield components and improves the nutrient status of the soil. The highest maize grain yield $\left(7494.3 \mathrm{~kg} \mathrm{ha}^{-1}\right)$ and above-ground biomass yield (18718.0 $\left.\mathrm{kg} \mathrm{ha}^{-1}\right)$ were obtained from the applications of $50 \%$ recommended NP fertilizer plus 50\% vermicompost which is based on the recommended $N$ equivalent respectively. Similarly, we found that a combination of both inorganic and organic fertilizers application also is the best strategy to improve major soil nutrients, maintain soil fertility. The economic analysis revealed that the highest net benefit of $\left(108,872.00 \mathrm{ETB}^{-1} \mathrm{a}^{-1}\right)$ was obtained from the application of 50\% recommended NP fertilizer plus 50\% vermicompost based on the recommended $N$ equivalence. Yet, the lowest yield and net benefit value were attained from the control or unfertilized plot. Therefore, this study suggests that an appropriate proportion of organic fertilizer with inorganic fertilizer not only for higher yield maize production with an assurance of potential economic returns to the small hold farmers but also improve and maintain the soil fertility and should be adopted with similar soil type and agro-ecologies.
\end{abstract}

Keywords: Grain yield, Maize, Organic and Inorganic fertilizers, Soil fertility 


\section{INTRODUCTION}

Ethiopia is the fifth largest producer of Maize (Zea mays L.) in Africa and smallholder farmers make up $94 \%$ of crop production with area coverage (16\%) and production (26\%) with about 6.5 million tons of production [1]. Nevertheless, the average estimated yields of maize for smallholder farmers in the country are about $3.2 \mathrm{t} \mathrm{ha}^{-1}$ which is much lower than the yield recorded under demonstration plots of 5-6 $\mathrm{t} \mathrm{ha}^{-1}$ [1]. Maize is an exhaustive cereal crop having higher potential than other cereals and absorbs a large number of nutrients from the soil during different growth stages. However, in Ethiopia, low soil fertility and low levels of input use are some of the major constraints for crop production [2]. Tropical smallholder farming systems including Ethiopia there are many interrelated factors, both natural and manmade, cause soil fertility decline. This decline may occur through leaching, soil erosion, lack of soil fertility restoring input, unbalanced nutrient use, and crop harvesting [3].

Unless the nutrients are replenished through the use of organic or mineral fertilizers, or partially returned through crop residues, or rebuilt more comprehensively through traditional fallow systems that allow restoration of nutrients and reconstruction of soil organic matter, soil nutrient levels decline continuously. Thus the recently acquired soil inventory data revealed that the deficiencies of most nutrients such as nitrogen (86\%), phosphorus (99\%), potassium (7\%), sulfur $(92 \%)$, born $(65 \%)$, zinc (53\%), copper, manganese, and iron are wide spread in Ethiopian soils [4]. Therefore, to alleviate nutrient deficiencies in soils and reduction in crop yield using affordable technologies were must. This include specially the use of combinations of organic and inorganic fertilizers and different integrated soil fertility management [5-9]. Achieving high maize yield requires an adequate and balanced supply of nutrients as declining soil fertility is a prominent constraint for maize production [10]. Many scholars who reported higher maize yields through the application of balanced use of high-quality organic inputs in combination with inorganic fertilizer as compared to the sole application of inorganic fertilizers [11-16]. Similarly, this has also confirmed works by [17] were found that the application of NP and FYM gave higher yields than the application of either NP or FYM alone for maize production. Zelalem, [18] was found that the application of $4 \mathrm{t} \mathrm{FYM} \mathrm{ha}{ }^{-1}$ incorporated with $75 / 60 \mathrm{~kg}$ of $\mathrm{N}$ and $\mathrm{P} \mathrm{ha}^{-1}$ was an economical and profitable combination in boosting maize yield. Similarly, Ahmad et al. [19] were found that the application of 50\% N through FYM and 50\% NPK through inorganic fertilizers increases maize the highest grain, biological yield and maximum benefits for smallholder farmers in the tropics. 
The application of inorganic fertilizer is to increase crop yield, but it becomes a chronic problem due to its cost and deterioration in soil physical, chemical, and biological properties of the soil. And also it cannot guarantee long-term productivity on many soils since they are not effective in maintaining soil fertility; So that urge sustainable options. Therefore, the integration of organic fertilizers like vermicompost and conventional composts with inorganic fertilizer sources were a viable option in improving maize yields without degrading soil fertility status. Moreover, very little information is available on the effects of abandoning manure application on crop productivity and soil quality. Therefore, keeping the above points in view, this study was undertaken to determine the influence of organic and inorganic fertilizers on yield and yield components of maize and soil fertility and to determine the economically optimum rate of organic and inorganic fertilizer for maize in Hawassa zuria, Sidama, Ethiopia. 


\section{MATERIAL AND METHODS}

\subsection{Experimental Site}

This study was carried out for three years (2018-2020) rainy (crops growing periods) seasons at Hawassa Zuria, Sidama Ethiopia it lies geographically at ( $6^{\circ} 57^{\prime} \mathrm{N}$ and $38^{\circ} 15^{\prime}$ E to $\left.7^{0} 10^{\prime}\right)$ location with altitude ranging from 1850-1934 m above sea level. The average mean annual rainfall and temperature are about $800 \mathrm{~mm}-1100 \mathrm{~mm}$ and the average minimum and maximum monthly temperatures are $12{ }^{\circ} \mathrm{C}$ and $26.7^{\circ} \mathrm{C}$ respectively. The rainy seasons are identified by the month that effective rainfall occurs. The rainfall is bimodal with longer growing periods from mid-May to mid- September and about $87 \%$ of the total rainfall and peak of the area occurs from mid-July to the end of August and which caused soil erosion and nutrient loss. According to [20] the dominant soil type of the site is Andosols, with the textural class of silty loam. The dominant crop in the area is maize.

\subsection{Treatments and Experimental Design}

The experiment was established in a randomized complete block design (RCBD) in a factorial arrangement with three replications. It consisted of 10 treatments in a combination of organic (vermicompost/conventional compost) and inorganic fertilizers and the organic source of fertilizers adjusted based on $\mathrm{N}$ equivalence.

Table 1: Details of treatment combination

\begin{tabular}{l|l}
\hline Treatments & Fertilizer types \\
\hline T1 & Control \\
\hline T2 & $100 \%$ of R-NP $(138 \mathrm{~N}$ and $92 \mathrm{P})$ \\
\hline T3 & $100 \%$ of vermicompost \\
\hline T4 & $100 \%$ of conventional \\
\hline T5 & $25 \%$ R-NP $+75 \%$ \\
\hline T6 & $50 \%$ of R-NP $+50 \%$ of vermicompost \\
\hline T7 & $75 \%$ of R-NP $+25 \%$ of vermicompost \\
\hline T8 & $25 \%$ of R-NP $+75 \%$ of conventional compost \\
\hline T9 & $50 \%$ of R-NP $+50 \%$ of conventional-compost \\
\hline T10 & $75 \%$ of R-NP $+25 \%$ of conventional- \\
\hline
\end{tabular}

Note- $R$-NP-which is recommended Nitrogen and Phosphorous

Where: Organic fertilizers were applied based on $N$-equivalence 
Organic fertilizer (vermicompost and conventional compost) were prepared at Wondo Genet Agricultural Research Center and applied before one month before sowing based on nitrogen equivalency. The improved maize variety $(\mathrm{BH}-546)$ was used sown in a row by $75 \mathrm{~cm}$ inter-row spacing and $30 \mathrm{~cm}$ intra-row spacing. Phosphorus-containing fertilizers triple superphosphate (TSP) was basally applied once at sowing to minimize losses and increase nutrient use efficiency. Nitrogen-containing fertilizer used from the Urea source and applied in the row two times; half at sowing and the other half during the maximum growth or tasseling period. Other agronomic management practices were applied as per recommendation.

\subsection{Crop harvest, soil sampling, and analyses}

At maturity, $3 \mathrm{~m}^{2}$ of maize was manually harvested from the middle of each plot to determine the plant height, ear height, ear length, above-ground biomass, grain yield; the grain yield which was adjusted to a $12.5 \%$ moisture content. Composite soil samples were sampled at random across all experimental at a depth of $0-15 \mathrm{~cm}$ before treatment application and after harvesting the crop soil samples were also collected immediately from each experimental unit to investigating the changes in soil chemical properties due to treatment application. The soil samples were air-dried, were processed, and analyzed for soil texture, $\mathrm{pH}$, organic matter, total nitrogen, available phosphorous, total sulfur, and cation exchange capacity were analyzed following the standard procedures outlines.

\subsection{Economic Analysis}

The economic returns from the application of each treatment were calculated based on the partial budgeting, which included only added costs and added benefits from the control treatment [21]. The average yield was adjusted downwards by $10 \%$ to reflect the difference between the experimental plot yield. Added costs included all the expenses for buying inorganic fertilizers (15.50 ETB kg-1 TSP and 10.25 ETB kg-1 Urea), conventional compost (1.50 ETB kg-1), and vermicompost (2.50 ETB kg${ }^{-1}$ ), while the added benefits referred to the gain obtained by selling maize grain was $14.50 \mathrm{ETB} \mathrm{kg}^{-1}$ at the local market price.

\subsection{Statistical Analysis}

The data were analyzed by using a two-way analysis of variance (ANOVA) using statistical analysis software (SAS) version 9.4 [22]. Whenever the treatment effects were significant, mean 
separations were made using the least significant difference (LSD) test at $(\mathrm{p} \leq 0.05)$ level of probability test by proc-mixed analysis [23].

\section{RESULT AND DISCUSSION}

\subsection{Physicochemical Properties of Initial Soil, Vermicompost, and Conventional Compost}

The initial soil sample collected from the experimental site before the commencement of the experiment was analyzed for the various Physico-chemical properties (Table 2). The analysis results indicated that soil particle size distribution of the experimental site was in proportions of sand, silt, and clay (39, 31, and $30 \%$ respectively (Table 2). Based on [20] soil textural classification the textural class of the soil of the site was silt loam and clay respectively. The $\mathrm{pH}$ water (1:2.5) level of experimental site soil result indicates that 6.7 (Table 2). According to [24] interpreting the soil $\mathrm{pH}$ of the site was near neutral and this most suitable for plant growth. It is a vital role in determining several chemical reactions and in influencing plant growth by affecting the activity of soil microorganisms and altering the solubility and availability of most of the essential plant nutrients and particularly the micronutrients such as $\mathrm{Fe}, \mathrm{Zn}, \mathrm{B}, \mathrm{Cu}$, and $\mathrm{Mn}$ [25].

The analysis result shows that the available $\mathrm{P}$ content was $6.4 \mathrm{mg} \mathrm{kg}^{-1}$ and was presented in table 2. The available $\mathrm{P}$ content of the soil was low according to the rating [26]. Okalebo et al., [27] reported that low soil test $\mathrm{P}$ values close to or below $10 \mathrm{mg} \mathrm{P}^{-1}$, the level below which $\mathrm{P}$ responses are expected. The total nitrogen content of sites was 0.12 which is ranged medium according to [28] classification. Similarly, organic carbon content was $2.75 \%$ which is ranged at a moderate level according to [28] classification. The total S content of the site is $22.51 \mathrm{mg} \mathrm{kg}^{-1}$. According to Havlin et al. [29] the available S content of the soil in the study area is low. The cation exchange capacity (CEC) of the soils was $23 \mathrm{Cmol}^{+} \mathrm{kg}^{-1}$ which is moderate based on [24] classification. (Table 2).

Vermicompost and Conventional Compost: The chemical compositions of vermicompost and conventional compost were presented in table 2 below. The result shows that the $\mathrm{pH}$ water $(1: 2.5)$ of vermicompost and conventional compost 7.8 and 7.4 respectively. Based on Hazelton, P., and B. Murphy, [24] interpretation the organic materials were slightly alkaline and it is the most and which is the most suitable for plant growth. According to the laboratory analysis result of total nitrogen and organic carbon of vermicompost was $(2.73 \%$ and $28.1 \%)$ respectively. However, total nitrogen and organic carbon on conventional compost were $1.93 \%$ and $30.1 \%$ respectively. Yadav et al., [30] reported total organic carbon reduction values ranging between 26 and $66 \%$ during 
vermicomposting of wastes of various sources. Suthar, [31] noted that the total N (range 2.49$3.17 \%$ ) was higher in the end product and the final $\mathrm{N}$ content could be related to the quality of the substrate used for worm feeding and probably because of mineralization of the organic matter. Suthar [32] suggested that the earthworms enhance the N levels in the vermicomposting substrate by adding their excretory products, mucus, body fluid, enzymes, and even through decaying tissues of dead worms in the vermicomposting subsystem.

The available $\mathrm{P}$ of vermicompost and conventional compost was $1.25 \mathrm{~g} \mathrm{~kg}^{-1}$ and $0.95 \mathrm{~g} \mathrm{~kg}^{-1}$ respectively. Similar results were obtained by [33] recorded a high percentage of P (2.68-3.61\%) in vermicompost. During vermicomposting, the release of available P content from the organic waste occurs partly by the earthworm gut phosphatases, and further release of P might be attributed to the P-solubilizing microorganisms present in the worm casts, causing conversion of phosphorus (P) to forms that are more bio-available to plants [34]. The K content on vermicompost (1.69) and conventional compost (0.92). In earlier studies, $\mathrm{K}$ values between $0.54 \%$ and $1.72 \%$ were reported [35]. The $\mathrm{C}$ : $\mathrm{N}$ ratio of the content on vermicompost and conventional compost is $28.1 \%$ and $30.1 \%$ respectively. According to [36] pointed out the decrease of carbon/nitrogen ratio is due to the rapid decomposition of the organic waste, and the mineralization and stabilization during the process of vermicomposting.

Table 2. Some physic-chemical properties initial soil, vermicompost, and conventional compost

\begin{tabular}{llll}
\hline Properties & Soil & Vermicompost & Conventional Compost \\
\hline Textural & Silt Loam & & \\
\hline Sand & $39 \%$ & & \\
\hline Silt & $31 \%$ & & \\
\hline Clay & $30 \%$ & 7.8 & 7.4 \\
\hline $\mathrm{pH} \mathrm{H} \mathrm{H}_{2} \mathrm{O}(1: 2.5)$ & 6.7 & 28.1 & 30.1 \\
\hline Organic Carbon $(\%)$ & 2.75 & 2.72 & 1.93 \\
\hline Total Nitrogen $(\%)$ & 0.12 & 1.25 & 0.95 \\
\hline Available P $\left(\mathrm{g} \mathrm{kg}^{-1}\right)$ & 6.4 & 1.69 & 0.92 \\
\hline $\mathrm{K}\left(\mathrm{g} \mathrm{kg}^{-1}\right)$ & 1.2 & & \\
\hline Total S mg kg & & \\
\hline $\mathrm{CEC}\left(\mathrm{Cmol}^{-1} \mathrm{~kg}^{-1}\right)$ & 22.51 & & \\
\hline $\mathrm{C}: \mathrm{N}$ & 23 & 10.33 & 15.59 \\
\hline $\mathrm{MC} \%$ & & 58.1 & 68.5 \\
\hline
\end{tabular}




\subsection{Soil Chemical Characteristics after Crop Harvest}

For evaluation of soil fertility status after last maize harvest, the soils were taken soon revealed that combined application of organic and inorganic fertilizer had significantly changed soil fertility and positive effects on the status of soil $\mathrm{pH}$, organic carbon content, total nitrogen, CEC, available $\mathrm{P}$ Available $\mathrm{K}$ and CEC are summarized in Table 3. The addition of organic and inorganic fertilizers in the soil changes soil $\mathrm{pH}$ (Table 3). The highest (8.0) and lowest $\mathrm{pH}(6.8)$ values were observed at the rate of combined application of $50 \%$ vermicompost based on $\mathrm{N}$ equivalency plus $50 \%$ recommended NP fertilizer $\mathrm{ha}^{-1}$ respectively. This indicates an improvement in the soil fertility status due to integrated nutrient management [15]. Consequently, the highest soil organic carbon content $3.5 \%$ and $2.9 \%$ were obtained from the combined application of $50 \%$ vermicompost based on $\mathrm{N}$ equivalency plus $50 \%$ recommended NP fertilizer $\mathrm{ha}^{-1}$ respectively (Table 4). However, the lowest soil organic carbon contents were obtained from control or unfertilized plot and followed by the application of organic fertilizer from conventional and vermicompost and 100\% recommended rate of NP alone (Table 3). Further, these results are also in concurrence with [37] who found that corn yield was increased by $35 \%$ when combined (inorganic and organic) nutrients were applied. Combined application of organic and inorganic nutrient sources improved synergism and synchronization between nutrient release and plant recovery thus resulted in better crop growth and yield [38].

Soil nutrients status of after application organic and inorganic fertilizer total nitrogen and available phosphorus and CEC were increased (Table 3). The result was revealed that the maximum TN $(0.41 \%)$ available phosphorus $\left.\left(19.5 \mathrm{~g} \mathrm{~kg}^{-1}\right)\right)$ and CEC $\left(40.1 \mathrm{Cmol}_{\mathrm{c}} \mathrm{kg}^{-1}\right)$ were obtained from the combined application of $50 \%$ vermicompost based on N equivalency plus $50 \%$ recommended NP fertilizer $\mathrm{ha}^{-1}$. This finding was in lined with Mubeen et al., [39] were found that combined application of organic and inorganic fertilizers is considered a good option to enhance nutrient recovery, increase the nutrient status of soil, plant growth, and ultimate yield. Similarly, Huang et al [38] were also reported that combined application of organic and inorganic nutrient sources improved synergism and synchronization between nutrient release and plant recovery thus resulted in better crop growth and yield. Finally, from this study, we found that the best strategy to improve productivity and maintain soil fertility, combination use of both inorganic and organic fertilizers were important. 
Table 3. Treatments effects on some s physicochemical properties of soil after crop harvest

\begin{tabular}{llccccc}
\hline No & Treatments & $\mathrm{pH}$ & $\mathrm{OC} \%$ & $\mathrm{TN} \%$ & $\mathrm{P}\left(\mathrm{g} \mathrm{kg}^{-1}\right)$ & $\mathrm{CEC}\left(\mathrm{Cmol} \mathrm{kg}^{-1}\right.$ \\
\hline 1 & Control & 6.8 & 1.3 & 0.05 & 6.5 & 22.1 \\
\hline 2 & $100 \%$ of R-NP $(138 \mathrm{~N}$ and $92 \mathrm{P})$ & 7.1 & 2.0 & 0.12 & 8.2 & 27.1 \\
\hline 3 & $100 \%$ of vermicompost & 7.9 & 1.9 & 0.13 & 10.5 & 25.9 \\
\hline 4 & $100 \%$ of conventional & 7.5 & 1.7 & 0.11 & 9.4 & 24.5 \\
\hline 5 & $25 \%$ R-NP $+75 \%$ of vermicompost & 7.3 & 2.3 & 0.17 & 10.5 & 29.3 \\
\hline 6 & $50 \%$ of R-NP $+50 \%$ of vermicompost & 8.0 & 3.5 & 0.41 & 19.5 & 40.1 \\
\hline 7 & $75 \%$ of R-NP+25\% of vermicompost & 7.6 & 2.5 & 0.15 & 12.7 & 28.1 \\
\hline 8 & $25 \%$ of R-NP $+75 \%$ of conventional compost & 7.7 & 2.1 & 0.15 & 10.3 & 26.9 \\
\hline 9 & $50 \%$ of R-NP $+50 \%$ of conventional compost & 7.9 & 2.9 & 0.27 & 16.6 & 35.3 \\
\hline 10 & $75 \%$ of R-NP $+25 \%$ of conventional compost & 7.4 & 2.2 & 0.14 & 11.9 & 27.6 \\
\hline
\end{tabular}

\subsection{Effects of Integrated Use of Organic and Inorganic Fertilizers on Plant Height, Ear Height, and Cob Length Maize}

The variation in plant height, ear height, and cob length of the maize crop for the different treatments is shown in Table 4. The pulled mean analysis revealed that of plant height, ear height, and cob length of maize were significantly $(<0.01)$ affected by the application of integrated use of organic and inorganic fertilizers (Table 4$)$. The longest plant height $(236.5 \mathrm{~cm})$, ear height $(139.9 \mathrm{~cm})$, and cob length $(15.2 \mathrm{~cm})$ were obtained from the application of $50 \%$ of recommended $\mathrm{NP}$ plus $50 \%$ of vermicompost based on $\mathrm{N}$ equivalence. However, the lowest plant height, ear height, and cob length were obtained from the control or unfertilized plot. This is because of, more photosynthetic activities of the plant on the account of an adequate supply of nitrogen since it is an essential requirement for ear growth [40]. 
Table 4. Effects of integrated use of organic and inorganic fertilizers on yield components of maize in 2018-2020 cropping seasons.

\begin{tabular}{|c|c|c|c|c|c|c|c|c|c|c|c|c|}
\hline \multirow{2}{*}{ Treatment $\left(\mathrm{kg} \mathrm{ha}^{-1}\right)$} & \multicolumn{3}{|c|}{2018} & \multicolumn{3}{|c|}{2019} & \multicolumn{3}{|c|}{2020} & \multicolumn{3}{|c|}{ pulled } \\
\hline & $\mathrm{PH}$ & $\mathrm{EH}$ & CL & $\mathrm{PH}$ & $\mathrm{EH}$ & CL & $\mathrm{PH}$ & $\mathrm{EH}$ & CL & $\mathrm{PH}$ & $\mathrm{EH}$ & CL \\
\hline Control & $127.9^{\mathrm{d}}$ & $89.8^{\mathrm{e}}$ & $9.9^{\mathrm{e}}$ & $187.9^{c}$ & $91.3^{\mathrm{c}}$ & $12.1^{\mathrm{d}}$ & $157.3^{\mathrm{d}}$ & $118.2^{\mathrm{e}}$ & $10.5^{\mathrm{d}}$ & $157.7^{\mathrm{f}}$ & $100.8^{\mathrm{d}}$ & 10.8 \\
\hline $100 \%$ RNP & $224.9^{a}$ & $153.9^{\mathrm{a}}$ & $14.2^{\mathrm{a}}$ & $218.3^{\mathrm{abc}}$ & $112.7^{\mathrm{abc}}$ & $15.1^{\mathrm{ab}}$ & $266.2^{\mathrm{a}}$ & $162.4^{\mathrm{a}}$ & 13.1 & $236.5^{\mathrm{a}}$ & $143.0^{\mathrm{a}}$ & $14.2^{\mathrm{bc}}$ \\
\hline $100 \%$ V.C & $148.5^{\mathrm{cd}}$ & $107.4^{\mathrm{d}}$ & $11.5^{\mathrm{cde}}$ & $205.2^{\mathrm{bc}}$ & $99.7^{\mathrm{bc}}$ & $13.1^{\mathrm{cd}}$ & $214.5^{\mathrm{c}}$ & $135.9^{\mathrm{d}}$ & $11.4^{\mathrm{cd}}$ & $189.4^{\mathrm{de}}$ & $114.3^{\mathrm{cd}}$ & 12.0 \\
\hline 100\% C.C & $160.1^{\mathrm{bcd}}$ & $107.0^{\mathrm{e}}$ & $12.0^{\mathrm{bcd}}$ & $193.4^{\mathrm{bc}}$ & $98.7^{\mathrm{bc}}$ & $15.5^{\mathrm{ab}}$ & $216.7^{\mathrm{c}}$ & $145.5^{\mathrm{d}}$ & $11.9^{\mathrm{cd}}$ & $190.1^{\text {ced }}$ & $117.0^{\mathrm{cd}}$ & $13.1^{\text {cde }}$ \\
\hline 25\% RNP+75\% V.C & $129.4^{\mathrm{d}}$ & $93.0^{\mathrm{de}}$ & $10.4^{\mathrm{de}}$ & $206.1^{\mathrm{bc}}$ & $108.1^{\mathrm{abc}}$ & $15.0^{\mathrm{ab}}$ & $216.7^{c}$ & $141.7^{\mathrm{bcd}}$ & $12.0^{\mathrm{bcd}}$ & $184.0^{\mathrm{e}}$ & $113.2^{\mathrm{cd}}$ & $12.5^{\mathrm{ef}}$ \\
\hline $50 \%$ RNP+50\% V.C & $188.5^{\mathrm{abc}}$ & $139.6^{\mathrm{abc}}$ & $15.0^{\mathrm{a}}$ & $255.1^{\mathrm{a}}$ & $132.1^{\mathrm{ab}}$ & $15.9^{\mathrm{a}}$ & $265.9^{c}$ & $148.1^{\mathrm{abc}}$ & $14.9^{\mathrm{a}}$ & $236.5^{\mathrm{a}}$ & $139.9^{\mathrm{a}}$ & $15.2^{\mathrm{a}}$ \\
\hline $75 \%$ RNP+25\% V.C & $202.7^{\mathrm{ab}}$ & $137.5^{\mathrm{bc}}$ & $14.0^{\mathrm{a}}$ & $196.1^{\mathrm{bc}}$ & $105.8^{\mathrm{bc}}$ & $14.9^{\mathrm{ab}}$ & $232.7^{\mathrm{a}}$ & $156.0^{\mathrm{abc}}$ & $12.9^{\mathrm{abc}}$ & $210.5^{\text {bcd }}$ & $133.1^{\mathrm{ab}}$ & $14.0^{\mathrm{cd}}$ \\
\hline $25 \%$ RNP+75\% C.C & $137.1^{\mathrm{d}}$ & $126.6^{\mathrm{c}}$ & $13.4^{\mathrm{abc}}$ & $203.7^{\mathrm{bc}}$ & $110.7^{\mathrm{abc}}$ & $14.0^{\mathrm{bc}}$ & $216.5^{c}$ & $135.1^{\mathrm{d}}$ & $11.7^{\mathrm{cd}}$ & $185.8^{\mathrm{e}}$ & $124.1^{b c}$ & $13.0^{\text {def }}$ \\
\hline $50 \%$ RNP+50\% C.C & $196.5^{\mathrm{ab}}$ & $135.2^{\mathrm{bc}}$ & $15.1^{\mathrm{a}}$ & $233.1^{\mathrm{ab}}$ & $142.3^{\mathrm{a}}$ & $16.0^{\mathrm{a}}$ & $263.2^{\mathrm{ab}}$ & $143.7^{\mathrm{cd}}$ & $14.0^{\mathrm{ab}}$ & $230.9^{\mathrm{ab}}$ & $140.4^{\mathrm{a}}$ & $15.0^{\mathrm{ab}}$ \\
\hline $75 \%$ RNP+25\% C.C & $200.3^{\mathrm{ab}}$ & $151.2^{\mathrm{ab}}$ & $13.5^{\mathrm{ab}}$ & $200.3^{\mathrm{bc}}$ & $100.1^{\mathrm{bc}}$ & $14.4^{\mathrm{abc}}$ & $236.1^{\mathrm{bc}}$ & $159.7^{\mathrm{ab}}$ & $13.4^{\mathrm{abc}}$ & $212.2^{\mathrm{bc}}$ & $137.0^{\mathrm{ab}}$ & $13.8^{\mathrm{cd}}$ \\
\hline $\mathrm{CV}$ & 15.9 & 7.9 & 10.0 & 12.1 & 18.6 & 7.1 & 7.4 & 5.6 & 9.7 & 11.8 & 11.2 & 8.3 \\
\hline LSD $@ \leq 0.05$ & $47.0^{* *}$ & $16.0^{* *}$ & $2.1^{* *}$ & $43.7^{* *}$ & $35.2^{* *}$ & $1.9^{*}$ & $29.0^{*}$ & $13.8^{* *}$ & $2.1^{* *}$ & $22.6^{* *}$ & $13.4^{* *}$ & $1.0^{*}$ \\
\hline
\end{tabular}

Where: PH-plant height, EH- ear height and, CL-cob length. RNP-recommended nitrogen and phosphorous, V.C-vermicompost and C.C-conventional compost; Numbers followed by the same letter in the same column are not significantly different at 5\% probability level

\subsection{Effects of Integrated Use of Organic and Inorganic Fertilizers on Above Ground Biomass, Grain Yield, and Straw Yield Maize}

The pulled mean analysis revealed that the application of organic and inorganic fertilizers can significantly $(<0.01)$ influence the maize above-ground biomass, grain yield, and straw yield (Table 5). The maximum above-ground biomass yield (18178.0 kg ha $\left.{ }^{-1}\right)$, grain yield (7494.3 $\left.\mathrm{kg} \mathrm{ha}^{-1}\right)$, and straw yield (11224.0 $\mathrm{kg} \mathrm{ha}^{-1}$ ) of maize were obtained from though the application of $50 \%$ of recommended NP plus $50 \%$ of $\mathrm{N}$ from vermicompost based on $\mathrm{N}$ equivalency. But lowest values above-ground biomass, grain yield, straw yield were obtained from unfertilized or control plot. 
The application of $50 \%$ of recommended NP plus $50 \%$ of $\mathrm{N}$ from vermicompost based on $\mathrm{N}$ equivalency was higher in grain yield by $115 \%$ and $24 \%$ and $21 \%$ compared to the control and application of $100 \%$ of recommended NP fertilizers, respectively. On the other hand, sole vermicompost application across all years produced statistically similar grain yield. The yield advantage relative to the control (unfertilized) treatment was $115 \%$ (Table 5) indicating the depletion of the soil and its strong response to fertilizer application. This is due to the optimum application of organic and inorganic fertilizer were roles in energy provision for seed formation and grain filling. This is an indication that the integrated use of organic and inorganic nutrient sources of fertilizers was advantageous over the use of inorganic fertilizer alone and also result in synergy and improved synchronization of nutrient release and uptake by the crop. This observation is consistent with findings of other researchers who reported higher maize yields through an application of high-quality organic inputs in combination with inorganic fertilizer as compared to sole application of inorganic fertilizers [11-14].

Similarly, this has also confirmed works by Khan et al.; Sanjivkumar; Ahmad et al; Ali et al; and Dilshad et al. $[15,16,19,41$, and 42] found that were found that application 50\% N through FYM, Compost vermicompost and 50\% NPK through inorganic fertilizers or combined use of organic and inorganic sources resulted in highest grain and yield components of maize compared to either organic or mineral fertilizers alone. Similarly, Shilpashree et al., [43] indicated that significantly higher straw and grain yields recorded with the application of 100\% (50\% $\mathrm{N}$ through inorganic fertilizers $+50 \% \mathrm{~N}$ through FYM (vermicompost), 150\% (75\% N through inorganic fertilizers + $75 \% \mathrm{~N}$ through FYM/vermicompost). And also, similar, the results obtained are in agreement with those of [40 and 44] they found that the production of grain yield might be due to better growth, development, and dry matter accumulation with a proper supply of nutrients to plant and increase in the availability of other plant nutrients with the respective source of nitrogen application. 
Table 5. Effects of integrated use of organic and inorganic fertilizers on yield of maize in 2018-2020 cropping seasons.

\begin{tabular}{|c|c|c|c|c|c|c|c|c|c|c|c|c|}
\hline \multirow[b]{2}{*}{ Treatment $\left(\mathrm{kg} \mathrm{ha}^{-1}\right)$} & \multicolumn{3}{|c|}{2018} & \multicolumn{3}{|c|}{2019} & \multicolumn{3}{|c|}{2020} & \multicolumn{3}{|c|}{ Pulled } \\
\hline & $\mathrm{AgBM}$ & SY & GY & $\mathrm{AgBM}$ & SY & GY & $\mathrm{AgBM}$ & SY & GY & $\mathrm{AgBM}$ & SY & GY \\
\hline Control & $9020^{\mathrm{d}}$ & $6595^{\mathrm{e}}$ & $2425.1^{\mathrm{ab}}$ & $9704^{\mathrm{d}}$ & $5545^{\mathrm{c}}$ & $4159.1^{d}$ & $14775.0^{c}$ & 10880.0 & $3895.2^{\mathrm{d}}$ & $11166.0^{\mathrm{e}}$ & $7673.0^{\mathrm{d}}$ & $3493.1^{\mathrm{e}}$ \\
\hline $100 \%$ RNP & $18889^{\mathrm{a}}$ & $12466^{\mathrm{a}}$ & $6422.4^{\mathrm{a}}$ & $14222^{\mathrm{bc}}$ & $8165^{\mathrm{abc}}$ & $6057.5^{\mathrm{abc}}$ & $18568.0^{\mathrm{abc}}$ & 12921.0 & $5646.2^{\mathrm{bc}}$ & $17226.0^{\mathrm{ab}}$ & $11184.0^{\mathrm{ab}}$ & $6042.0^{\mathrm{bc}}$ \\
\hline 100\% RN V.C & $11899^{\mathrm{bcd}}$ & $7666^{\text {bcd }}$ & $4233.1^{\mathrm{bcd}}$ & $13926^{\mathrm{cd}}$ & $9202^{\mathrm{abc}}$ & $4724.4^{\mathrm{cd}}$ & $15261.0^{\mathrm{bc}}$ & 10470.0 & $4791.3^{\mathrm{cd}}$ & $13695.0^{\mathrm{d}}$ & $9112.0^{\mathrm{abcd}}$ & $4582.9^{\mathrm{e}}$ \\
\hline 100\% RN C.C & $11485^{\text {bcd }}$ & $7365^{\mathrm{cd}}$ & $4119.7^{\mathrm{cd}}$ & $13333^{\mathrm{cd}}$ & $8818^{\mathrm{abc}}$ & $4515.6^{\mathrm{cd}}$ & $15378.0^{\mathrm{bc}}$ & 10379.0 & $4999.6^{\mathrm{cd}}$ & $13399.0^{\mathrm{de}}$ & $8854.0^{\text {bcd }}$ & $4544.9^{\mathrm{e}}$ \\
\hline $25 \%$ RNP $+75 \%$ V.C & $11051^{\mathrm{cd}}$ & $7405^{\mathrm{de}}$ & $3645.2^{\mathrm{de}}$ & $12148^{\mathrm{cd}}$ & $6602^{\mathrm{bc}}$ & $5545.9^{\text {bcd }}$ & $16072.0^{\mathrm{abc}}$ & 11745.0 & $4326.9^{d}$ & $13090.0^{\mathrm{de}}$ & $8584.0^{\mathrm{ad}}$ & $4506.0^{\mathrm{e}}$ \\
\hline $50 \%$ RNP+50\% V.C & $17960^{\mathrm{a}}$ & $11258^{\mathrm{a}}$ & $6701.6^{\mathrm{a}}$ & $18889^{\mathrm{a}}$ & $11217^{\mathrm{a}}$ & $7671.5^{\mathrm{a}}$ & $19306.0^{\mathrm{a}}$ & 11196.0 & $8109.8^{\mathrm{a}}$ & $18718.0^{\mathrm{a}}$ & $11224.0^{\mathrm{a}}$ & $7494.3^{\mathrm{a}}$ \\
\hline $75 \%$ RNP+25\% V.C & $18455^{\mathrm{a}}$ & $12710^{\mathrm{ab}}$ & $5744.4^{\mathrm{ab}}$ & $14815^{\mathrm{abc}}$ & $9904^{\mathrm{ab}}$ & $4911.2^{\mathrm{bcd}}$ & $16712.0^{\mathrm{abc}}$ & 11046.0 & $5665.7^{\mathrm{bc}}$ & $16660.0^{\mathrm{abc}}$ & $11220.0^{\mathrm{a}}$ & $5440.5^{\mathrm{cd}}$ \\
\hline $25 \%$ RNP+75\% C.C & $13131^{\mathrm{bc}}$ & $8871^{\text {bcd }}$ & $4260.1^{\mathrm{bcd}}$ & $15704^{\mathrm{abc}}$ & $10401^{\mathrm{ab}}$ & $5303.1^{\text {bcd }}$ & $15766.0^{\mathrm{abc}}$ & 10936.0 & $4830.2^{\mathrm{cd}}$ & $14867.0^{\mathrm{cd}}$ & $10069.0^{\mathrm{abc}}$ & $4797.8^{\mathrm{de}}$ \\
\hline $50 \%$ RNP+50\% C.C & $14535^{\mathrm{b}}$ & $8400^{a}$ & $6135.4^{\mathrm{a}}$ & $18444^{\mathrm{ab}}$ & $11795^{\mathrm{a}}$ & $6649.7^{\mathrm{ab}}$ & $19080.0^{\mathrm{ab}}$ & 12643.0 & $6436.7^{b}$ & $17353.0^{\mathrm{ab}}$ & $10946.0^{\mathrm{ab}}$ & $6407.3^{b}$ \\
\hline $75 \%$ RNP+25\% C.C & $18485^{\mathrm{a}}$ & $12971^{\text {bcd }}$ & $5513.7^{\mathrm{abc}}$ & $12148^{\mathrm{cd}}$ & $7484^{\mathrm{abc}}$ & $4663.9^{\mathrm{cd}}$ & $18162.0^{\mathrm{abc}}$ & 13194.0 & $4968.6^{\text {cd }}$ & $16265.0^{\mathrm{bc}}$ & $11216.0^{\mathrm{a}}$ & $5048.7^{\text {de }}$ \\
\hline $\mathrm{CV}$ & 13.7 & 22.1 & 18.0 & 17.8 & 19.1 & 20.0 & 13.5 & 20.0 & 12.2 & 15.8 & 24.2 & 17.0 \\
\hline LSD@<0.05 & 3418.7 & 3750.0 & 1520.5 & 4382.2 & 4336.4 & 1882.9 & 3902.2 & 4073.5 & 1118.8 & 2261.2 & 2336.8 & 841.2 \\
\hline
\end{tabular}

Where: AgBM-above-ground biomass, SY- straw yield and GY-grain yield; Numbers followed by the same letter in the same column are not significantly different at $5 \%$ probability level

\subsection{Economic Analysis}

The result of the economic analysis revealed that all treatments were economically feasible as the net benefit values were greater than zero (NBV>0) and given in table 6. On this note, the application of 50\% recommended NP fertilizer plus 50\% vermicompost based on N equivalency with the highest NPV of $\left(108,872.00 \mathrm{ETB} \mathrm{ha}^{-1}\right)$ is considered to be the most economically viable treatment method. While the control or unfertilized treatment gives the lowest net benefit (51721.50 ETB ha-1). This result is agreed with, Girma and Gebreyes [45] were found that application of 50\% vermicompost plus 50\% $\mathrm{N}$ and $\mathrm{P}$ fertilizers, whereas the control treatment (no application of input), gave the lowest net benefit in tef. Likewise, the highest marginal rate of the return (MRR\%) was attained from the application of $50 \%$ recommended NP plus 50\% vermicompost (Table 6). Tolera et al., [46] were reported the highest marginal rate of return of 980\% was obtained with the application of 50:50\% farmyard manure: with recommended NP for barley production. 
Table 6. Effects of integrated use of organic and inorganic fertilizers on economic profitability of maize production

\begin{tabular}{|c|c|c|c|c|c|}
\hline Treatment $\left(\mathrm{kg} \mathrm{ha}^{-1}\right)$ & $\operatorname{AGY}\left(\mathrm{kg} \mathrm{ha}^{-1}\right)$ & GBV (ETB kg-1) & TVC $\left(\mathrm{ETB} \mathrm{kg}^{-1}\right)$ & NBV $\left(\mathrm{ETB} \mathrm{kg}^{-1}\right)$ & MRR\% \\
\hline Control & 3493.1 & 52396.5 & 675 & 51721.5 & \\
\hline $100 \%$ RNP & 6042 & 90630 & 3401.5 & 87228.5 & 591.8 \\
\hline $100 \%$ V.C & 4582.9 & 68743.5 & 3675 & 65068.5 & \\
\hline 100\% C.C & 4544.9 & 68173.5 & 4175 & 63998.5 & \\
\hline $25 \%$ RNP+75\%V.C & 4506 & 67590 & 3609 & 63981 & \\
\hline $50 \%$ RNP+50\% V.C & 7494.3 & 112415 & 3543 & 108872 & 15295.4 \\
\hline $75 \%$ RNP+25\% V.C & 5440.5 & 81607.5 & 3467.5 & 78140 & \\
\hline $25 \%$ RNP+75\% C.C & 4797.8 & 71967 & 6084 & 65883 & \\
\hline $50 \%$ RNP+50\% C.C & 6407.3 & 96109.5 & 5193 & 90916.5 & 1088.0 \\
\hline $75 \%$ RNP+25\% C.C & 5048.7 & 75730.5 & 4292.5 & 71438 & \\
\hline
\end{tabular}

Where, ETB = Ethiopian Birr (currency); $A G Y=$ adjusted grain yield, GBV= growth benefit value, $T C V=$ Total variable cost $; N B V=$ Net benefit value; $M R R=$ Marginal rate of return

\subsection{Conclusions and Recommendation}

These findings indicate that appropriate organic and inorganic fertilizer combination is beneficial to maize production and maintaining the soil nutrient balance. Based on the results of this study combination of inorganic and organic fertilizers with an application of 50\% recommended NP fertilizer plus $50 \%$ vermicompost is recommended to increase the yield of maize and improve soil fertility. The higher grain yield of maize was obtained from the integration of $50 \%$ recommended NP fertilizer plus 50\% vermicompost based on N equivalence with recommended NP fertilizer application. Application of 50\% recommended NP fertilizer plus 50\% vermicompost gave a net profit advantage of 108,872.0 $\mathrm{ETB} \mathrm{ha}^{-1}$ and recommended for optimum grain yield and economical profitable maize production in the area. Finally, this study suggests that an appropriate proportion of organic fertilizer with inorganic fertilizer not only for higher yield maize production with an assurance of economic returns but also provides enough nutrients and should be adopted with similar soil type and agro-ecologies. 


\section{Acknowledgment}

The authors thank the Ethiopia Institute of Agricultural Research, Natural Resources Management Research for supporting the fund. The authors gratefully acknowledge to Wondo Genet Agricultural Research Center and all the technical and field assistants of the Natural Resources Management Research Process for unreserved effort during executing the experiment.

\section{Conflicts of Interest}

The authors declare that there are no conflicts of interest regarding the publication of this paper. 


\section{REFERENCES}

[1]. CSA (Central Statistical Agency). 2014. Agricultural Sample Surveys. CSA, Addis Ababa, Ethiopia.

[2]. Abreha, K., H. Gerekidan, T. Mamo, and K. Tesfaye. 2013. Wheat crop response to lime materials and $\mathrm{N}$ and $\mathrm{P}$ fertilizers in acidic soils of Tsegedie highlands, Northern Ethiopia. Agric. For., 2: 126-135.

[3]. Donovan and F. Casey. 1998. Soil Fertility Management in Sub-Saharan Africa. (World Bank Technical Paper No. 408. Washington, DC. The World Bank (1998), pp. 61.

[4]. EthioSIS (Ethiopian Soil Information System). 2016. Soil Analysis Report. Agricultural Transformation Agency. Adis Abeba, Ethiopia.

[5]. Palm C.A., Gachengo C.N., Delve R.J., Cadisch G. and Giller K.E. 2001. Organic inputs for soil fertility management in tropical agroecosystems: application of an organic resource database. Agri. Ecosys. Environ. 83: 27-42.

[6]. Okalebo J.R., Palm C.A., Gichuru M., Owuor J.O., Othieno C.O., Munyampundu A., Muasya R.M. and Woomer P.L. 1999. Use of wheat straw, soybean trash and nitrogen fertilizer for maize production in the Kenya highlands. African Crop Sci. J. 7: 423-432.

[7]. Okalebo, J.R. and Nandwa, S. 1997. Effect of organic materials with and without inorganic P fertilizer on maize yield mainly in P deficient soil. Report on Activity 3.1.1. Soil Fertility and Plant Nutrition Research Programme, KARI, EU Funded pp. 10.

[8]. Jama, B, Swinkels, R.A. and Buresh, R.J. 1997. Agronomic and economic evaluation of organic and inorganic sources of phosphorus for maize. Agron. J. 89: 597-604.

[9]. Woomer, P.L., Okalebo, J.R. and Sanchez, P.A. 1997. Phosphorus replenishment in Western Kenya: from field experiments to an operational strategy: African Crop Science Conference Proceedings 3(1), 559-570.

[10]. Barbieri, P.A., H. E. S. Rozas, and F.H. Andrade. 2012. Nitrogen use efficiency in maize as affected by nitrogen availability and row spacing. Agron. J., 100: 1094-1100.

[11]. Serafim B, Oginga B, Mugwe JN. 2013. Effects of manure, lime, and mineral P fertilizer on soybean yields and soil fertility in a humic nitisol in the central highlands of Kenya. Int J Agric Sci Res 2:283-291.

[12]. Endris S and Dawid J. 2015. Yield response of maize to integrated soil fertility management on acidic nitosol of southwestern Ethiopia. J Agron 14:152-157. 
[13]. Usman M, Madu VU, Alkali G. 2015.The combined use of organic and inorganic fertilizers for improving maize crop productivity in Nigeria. Int J Sci Res Pub 5:1-7.

[14]. Baloch, P.A.; Abro, B.A; chandio, A.S.; Depar, N. and Anssari, M.A. 2015. Growth and yield response of maize to the integrated use of Gliricidia Sepium, farm manure, and NPK fertilizers. Pakistan J. Agric., Agril. Engg., Vet. Sa'.,31(1):14-23.

[15]. Khan, S.; Mohammad, T.J.; Bilal, A.; Tariq, S. and Wisal, A. 2016. Yield and yield components of maize as affected by integrated management of sheep manure and urea fertilizer. Middle-East J. Agric. Res., 5(4): 522-533.

[16]. Sanjivkumar. V. 2014. Effect of integrated nutrient management on soil fertility and yield of maize crop (Zea mays) in Entic Haplustart in Tamil Nadu, India. Journal of Applied and Natural Science 6 (1): 294-297

[17]. Negassa W; Kefalew Negisho; Friesen DK; Ransom J; Abebe Yadessa. 2004a. Determination of optimum Farmyard manure and NP fertilizers for maize on farmer's fields. pp 387-393. In: Friesen DK and Palmer AFE. (eds.). Integrated Approaches to higher maize productivity in the new millennium: Proceedings of the Seventh Eastern and Southern African Regional Maize Conference, 5-11 February 2001, Nairobi, Kenya: CIMMYT.

[18]. Zelalem Bekeko. 2013. Effect of nitrogen and phosphorus fertilizers on some soil properties and grain yield of maize (BH-140) at Chiro, Western Hararghe, Ethiopia. African Journal of Agricultural Research 8(45): 5693-5698.

[19]. Ahmad W, Z. Shah, F. Khan, S. Ali, and W. Malik. 2013. "Maize yield and soil properties as influenced by integrated use of organic, inorganic and bio-fertilizers in a low fertility soil," Soil Environ., vol.32, pp. 121-129. Available: www.se.org.pk.

[20]. FAO (Food and Agriculture Organization). 2014. World Reference Base for Soil Resources International soil classification system for naming soils and creating legends for soil maps. World Soil Resources Reports No. 106. Food and Agriculture Organization of the United Nations (FAO), Rome, Italy.

[21]. CIMMYT (The International Maize and Wheat Improvement Center). 1988. From Agronomic Data to Farmer Recommendations. An economic Training Manual completely revised edition. Mexico, D. F.

[22]. SAS (Statistical Analysis System Institute). 2014. SAS Version 9.4 (C) 2002-2012. SAS Institute, Inc., Cary, North Carolina, USA.

[23]. Gomez AK, and AA Gomez. 1984.Statistical procedure for agricultural research $2^{\text {nd }}$ (Ed.). A Wiley Inter-Science Publication, New York. 
[24]. Hazelton, P., and B. Murphy, 2016. Interpreting soil test results: What do all the numbers mean $2^{\text {nd }}$ Edition. CSIRO Publishing. 152p.

[25]. Sumner, M.E. 2000. Handbook of Soil Science, CRC Press, Boca Raton, FL.

[26]. Cottenie A. 1980. Soil and plant testing as a basis of fertilizer recommendations. FAO soil bulletin 38/2. Food and Agriculture Organization of the United Nations, Rome.

[27]. Okalebo, J.R., Gathua, K.W. and Woomer, P.L. 1993. Laboratory Methods of Soil and Plant Analysis: A working manual. TSBF-UNESCO, Nairobi, EPZ Publishers, Nairobi, Kenya, $88 \mathrm{p}$.

[28]. Tekalign Tadese. 1991. Soil, plant, water, fertilizer, animal manure, and compost analysis. Working Document No. 13. International Livestock Research Center for Africa, Addis Ababa, Ethiopia.

[29]. Havlin, J.L., Beaton, J.D., Tisdale, S.L., Nelson and W.L., 2005. Soil Fertility and Fertilizers: An Introduction to Nutrient Management. Pearson Prentice Hall, Upper Saddle River, New Jersey.

[30]. Yadav KD, Tare V, Ahammed MM. 2010. Vermicomposting of source separated human faces for nutrient recycling. Waste Manag 30:50-56.

[31]. Suthar S. 2009. Bioremediation of agricultural wastes through vermicomposting. Bioremed $\mathrm{J} 1$.

[32]. Suthar S (2007) Production of vermifertilizer from guar gum industrial waste by using composting earthworm Perionyxsansibaricus (Perrier). Environmentalist 27(3):329-335. https://doi.org/10.1007/ s10669-007-9032-9.

[33]. Marlin CJ, Rajeshkumar KT (2012) A study on sustainable utility of sugar mill effluent to vermicompost. Adv Appl Sci Res 3(2):1092-1097. http://www.imedpub.com/articles/astudy-on-sustainabl e-utility-of-sugar-mill-effluent-to-vermicompost.pdf.

[34]. Goswami L, Patel AK, Dutta G, Bhattacharyya P, Gogoi N, Bhattacharya SS. 2013. Hazard remediation and recycling of tea industry and paper mill bottom ash through vermiconversion. Chemosphere 92 6:708-713.

[35]. Waseem MA, Giraddi RS, Math KK (2013) Assessment of nutrients and micro flora in vermicompost enriched with various organics. J Exp Zool India 16:697-703.

[36]. Kaushik P, Garg VK. 2003. Vermicomposting of mixed textile mill sludge and cow dung with epigeic earthworm Eisenia foetida. Bioresour Technol 90(3):311-316. https://doi.org/10.1016/S0960 -8524(03)00146-9. 
[37]. Shisanya, C.A.; Mucheru, M.W.; Mugendi, D.N.; Kung'u, J.B. 2009. Effect of organic and inorganic nutrient sources on soil mineral nitrogen and maize yields in central highlands of Kenya. Soil Tillage Res. 103, 239-246. [CrossRef].

[38]. Huang GF, Fang M, Wu QT, Zhou LX, Liao XD, Wong JWC. 2001. Co-composting of pig manure with leaves. Environ Technol 22:1203-1212.

[39]. Mubeen, K., Iqbal, A., Hussain, M., Zahoor, F., Siddiqui, M.H., Mohsin, A.U., Bakht, H.F.S.G., Hanif, M. 2013. Impact of Nitrogen and Phosphorus on the Growth, Yield and Quality of Maize (Zea mays L.) Fodder in Pakistan. Philipp. J. Crop Sci. 38(2), 43-46.

[40]. Fanuel, L., and Gifole, G. 2013. Growth and yield response of maize (Zea mays L.) to variable rates of compost and inorganic fertilizer integration in Wolaita, Southern Ethiopia. Am.J. Plant Nutr.Fert. Technol., 3(2):43-52.

[41]. Ali K., S. K. Khali, F. Munsif Abdurrab, K. Nawab, A. Z. Khan, A. Kamal, and Z. H. Khan, 2012."The response of maize to various nitrogen sources and tillage practices," Sarhad J. Agric., vol. 28, pp. 9-14,

[42]. Dilshad, M.D., M.I Lone, G. Jilani, M.A. Malik, M. Yousaf, R. Khalid, and F. Shamim. 2010. Integrated Plant Nutrient Management (IPNM) on maize under rained condition. Pak. J. Nutr.,9: 896-901.

[43]. Shilpashree V M, Chidanandappa H M, Jayaprakash R, and Punitha B C. 2012. Influence of Integrated. Nutrient Management Practices on Productivity of Maize Crop. Indian Journal of Fundamental and Applied Life Sciences 2(1): 45-50.

[44]. Magda, A.E.; Sabar, M.Z. and Mohamed, A.A. 2015. Effect of mineral fertilizer integration with organic manure on growth, yield, and quality of maize (Zea mays L.). J. soil Sci. and Agric. Eng., Mansoura univ., 6(2):165-179.

[45]. Girma C. and Gebreyes G. 2017. Effect of Organic and Inorganic Fertilizers on Growth and Yield of Tef (Eragrostis tef) in the Central Highlands of Ethiopia Ethiop. J. Agric. Sci. 27(1) 77- 88 (2017).

[46]. Tolera A., Tolcha T., Tesfaye M., Haji K., and Buzuayehu T. 2018. Effect of Integrated Inorganic and Organic Fertilizers on Yield and Yield Components of Barley in Liben Jawi District. Hindawi. International Journal of Agronomy. Volume 2018, Article ID 2973286, 7 pages. https://doi.org/10.1155/2018/2973286. 